\title{
PEMBINAAN DAN PENDAMPINGAN UMKM SEBAGAI UPAYA PEMBERDAYAAN EKONOMI KELUARGA PADA MASYARAKAT PESISIR
}

\author{
Ade Sandra Dewi*1, Ani Pujiati ${ }^{2}$, Arif Saifudin ${ }^{3}$, Rangga Yoga Winata ${ }^{4}$ \\ ${ }_{1,2,3,4}$ Universitas Sang Bumi Ruwa Jurai, \\ e-mail:*142.adedewi@gmail.com, ${ }^{2}$ anipujiati@gmail.com
}

\begin{abstract}
Abstrak
Way Tataan adalah kelurahan yang berada di Kecamatan Teluk Betung Timur, Kota Bandar Lampung. Salah satu SDA yang terdapat di Kelurahan Way Tataan yang luar biasa adalah bidang perikanan dimana hasil laut di PPI Lempasing dapat menciptakan lapangan pekerjaan untuk ribuan orang baik laki-laki, perempuan maupun anak-anak. kedua sumber daya alam ini memberikan kontribusi pendapatan daerah yang cukup segnifikan. Sebagian besar mata pencahariannya adalah nelayan, nelayan kapal cantrang, kapal payang dan berat .walaupun ada juga sebagian masyarakatnya yang memiliki UMKM seperti pengelolaan emping, panglong, pengelolaan ulit ikan dan ikan pilet, terasi yang masih harus dikembangkan baik dari sistem pengelolaannya maupun dari bahan bakunya dan juga sistem market atau pemasarannya. Penulis melakukan kegiatan Pengabdian Masyarakat pada UMKM Pengolahan Empling Ceplis Melinjo di kelurahan Way Tataan. Kegiatan ini dilakukan dengan menggunakan metode permainan, ceramah, tanya jawab dan diskusi. Pada akhirnya, Pelatihan Pengelolaan UMKM ini berjalan sangat aktif dan komunikatif. Setelah diberikan materi yang berkaitan dengan strategi pemasaran secara online atau daring melalui MarketPlace (Facebook) maupun Instagram, para peserta dapat memahami materi dan termotivasi terlihat dengan antusiasnya peserta dalam berdiskusi.
\end{abstract}

Kata Kunci: Emping melinjo, Masyarakat Pesisir, Penjualan Offline dan Online, UMKM.

\begin{abstract}
Way Tataan is a village located in Teluk Betung Timur District, Bandar Lampung City. One of the extraordinary natural resources in Way Tataan Village is in the field of fisheries where marine products at PPI Lempasing can create jobs for thousands of people, both men, women and children. these two natural resources contribute significantly to regional income. Most of their livelihoods are fishermen, cantrang boat fishermen, payang and heavy boats. Although there are also some people who have MSMEs such as emping management, panglong, fish shell management and pilet fish, shrimp paste which still has to be developed both from the management system and from the raw materials and also the market or marketing system. The author carried out Community Service activities at the MSME Empling Ceplis Melinjo Processing in the Way Tataan village. This activity is carried out using the game, lecture, question and answer method and discussion. In the end, the MSME Management Training was very active and communicative. After being given material related to online or online marketing strategies through MarketPlace (Facebook) or Instagram, the participants were able to understand the material and were motivated by the enthusiasm of the participants in the discussion..
\end{abstract}

Keywords: Ceplis Melinjo Chips, Coastal Society, Offline and Online Sales, MSME's

\section{PENDAHULUAN}

Way Tataan adalah kelurahan yang berada di Kecamatan Teluk Betung Timur, Kota Bandar Lampung, Indoensia. Sumber daya alam yang terdapat di Kelurahan Way Tataan 
Kecamatan Teluk Betung Timur yang menjadi unggulan adalah dibidang perikanan yang mana hasil laut di PPI Lempasing dapat menciptakan lapangan pekerjaan untuk ribuan orang baik lakilaki, perempuan maupun anak-anak. kedua sumber daya alam ini memberikan kontribusi pendapatan daerah yg cukup segnifikan setiap tahunnya [1].

Dengan luas 337 ha wilayah kelurahan Way Tataan kecamatan teluk betung timur Bandar lampung ini mampu menciptakan sumber daya alam yang sangat luar biasa terutama dibidang hasil ikan laut yang kegiatan bongkar muatnya dapat kita lihat di area Tpi lempasing.kegiatan bongkar muat ini dilakukan oleh kapal cantrang yang berukuran 30Gt dan ada juga kapal paying yang berukuran seitar 8GT yang mana hasil tangkapan ikannya bervariatif dari mulai ikan krisi, cumi, ikan bawal, simba, kakap dan juga ikan kembung. yang mana keadaan ini sangat dapat berpengaruh dalam peningkatan ekonomi suatu daerah dan bahkan peningkatan pembangunan ekonomi nasional [2].

Pada umumnya penduduk yang keadaan ekonominya kurang terpenuhi, penduduk tersebut akan berusaha untuk meningkatkan perekonomianya, maka sebagian anak bekerja membantu orang tua sebagai salah satu memenuhi kebutuhan sehari-hari [3]. Ada beberapa anak-anak dibawah umur yang bekerja sebagi nelayan untuk membantu orang tuanya. Sebagian besar mata pencahariannya adalah nelayan yang menggunakan kapal cantrang [4].
Walaupun ada juga sebagian masyarakatnya yang memiliki UMKM seperti pengelolaan emping, panglong, pengelolaan ulit ikan dan ikan pilet, terasi yang masih harus dikembangkan baik dari sistem pengelolaan [5], bahan baku [6], dan juga sistem market atau pemasarannya [7].

Ada 2 (dua) jenis emping melinjo yang diproduksi di Kelurahan Way Tataan, yaitu emping melinjo pipih dan emping ceplis melinjo. Emping melinjo pipih adalah emping atau keripik yang bentuknya lebar dan dibuat dari gabungan beberapa buah biji melinjo. Sedangkan emping ceplis melinjo adalah emping atau keripik yang dibuat dari biji melinjo yang telah tua [8].

Tim Pengabdian melakukan kegiatan Pengabdian Masyarakat pada usaha pengolahan emping ceplis melinjo merk Sakina milik Ibu Kesuma Dewi dan keluarga yang sudah memproduksi emping ceplis melinjo sejak tahun 1991 atau kurang lebih sudah 30 (tiga puluh) tahun membuat emping ceplis melinjo dan pemasarannya masih dititipkan di toko-toko pasar tradisional terdekat dari kelurahan Way Tataan.

Adapun kendala yang dihadapi dalam memproduksi empling ceplis melinjo ini adalah : (1) Stock bahan baku tergantung oleh stock buah melinjo yang berbuah tidak sepanjang tahun atau bersifat musiman; (2) Tenaga kerja untuk memproduksi emping ceplis ini masih terbatas anggota keluarga; (3) keahlian yang 
memproduksi emping ceplis ini hanya dimiliki anggota keluarga dan bersifat turun temurun; (4) Kemasan emping ceplis masih sederhana dengan label kemasan yang kurang menarik minat pembeli sehingga penjualan masih ke pasar tradisional; (5) Penjualan produk empling ceplis ini masih manual (offline), belum secara online atau menggunakan media social atau $e$ commerce

\section{METODE}

\subsection{Metode yang Digunakan}

a. Metode ceramah digunakan oleh pemateri unuk menjelaskan materi yang berkaitan dengan materi pengelolaan UMKM secara profesional, dengan menggunakan pencatatan pembukuan sederhana sehingga dapat diketahui berapa keuntungan berih penjualan sesudah dikurangi dengan biaya produksi.

b. Metode diskusi digunakan untuk memperdalam materi bahasan baik bentuk tanya jawab secara perorangan maupun kelompok lebih dari satu orang. c. Metode pemberian motivasi dalam bentuk permainan berkelompok.

\subsection{Target Sasaran}

Khalayak sasaran dalam kegiatan pengabdian adalah para penggiat UMKM Emping Ceplis Melinjo merk Sakina milik Ibu Kesuma Dewi dan keluarga, yang berlokasi di Kelurahan Way Tataan. Pelatihan melibatkan seluruh anggota keluarga Ibu Kesuma Dewi yang membatu proses produksi emping ceplis melinjo yangberjumlah 5 (orang), yang bertugas dibagian : 1) proses sangrai biji melinjo yaitu menggoreng biji melinjo dengan menggunakan pasir pantai diatas tungku api dan penggorengan tembikar, 2) proses pengelupasan kulit melinjo setelah selesai disangrai, 3) proses pemipihan biji melinjo denga alat pemukul khusus, 4) proses garang yaitu memanggang emping ceplis melinjo diatas bara api denga cara dibolak-balik menggunakan tangan, dan 5) proses penggorengan emping ceplis melinjo dengan minyak goreng diatas kuali denga api panas.

\subsection{Jadwal Kegiatan}

Kegiatan Pengabdian kepada masyarakat dilaksanakan selama 40 hari yaitu tanggal 01 April 2021 sampai tanggal 10 April 2021 di Kantor Kelurahan Way Tataan, Teluk Betung Timur, Bandar Lampung. Adapun kegiatan penyuluhan kepada penggiat UMKM dilaksanakan pada tanggal 07 Maret 2021 di Kantor Kelurahan Way Tataan, Teluk Betung Timur, Bandar Lampung. 


\section{HASIL DAN PEMBAHASAN}

Kegiatan ini dilakukan dengan menggunakan metode permainan, ceramah, tanya jawab dan diskusi. Kegiatan ini merupakan pengabdian dalam rangka menumbuhkan minat dan kesadaran para penggiat UMKM Emping Ceplis Melinjo di Kelurahan Way Tataan, Kecamatan Teluk Betung Selatan, Kota Bandar Lampung, khususnya Emping Ceplis Melinjo merk Sakina untuk dapat mengelola UMKM secara profesional dengan membuat pembukuan sederhana serta meningkatkan penjualan produk emping ceplis melinjo baik secara offline maupun online (daring) dalam upaya pemberdayaan ekonomi keluarga pada masyarakat Pesisir di Masa Covid-19.

Pelatihan ini diikuti oleh peserta dari para penggiat UMKM Kelurahan Way Tataan, Kecamatan Teluk Betung Selatan, Kota Bandar Lampung,, khususnya UMKM Emping Ceplis Melinjo merk Sakina. Peserta berasal anggota keluarga dari Ibu Kesuma Dewi berjumlah 5 (lima )orang selaku penggiat emping ceplis melinjo.

Berdasarkan hasil survey dan konsultasi dengan penggiat UMKM Emping Ceplis merk Sakina milik Ibu Kesuma Dewi maka pada tanggal 07 Maret 2021 telah dilaksanakan kegiatan sosialisasi dan pelatihan pengelolaan
UMKM, dalam meningkatkan pemahaman para pengelola UMKM dalam mengelola secara profesional di Kelurahan Way Tataan, Kecamatan Teluk Betung Timur, Kata Bandar Lampung.

Peserta pelatihan pada tahap awal (sesi pagi), diberikan materi tentang keunggulan produk UMKM Emping Ceplis Melinjo merk Sakina. Peserta pada tahap kedua (sesi siang) diberikan pelatihan penyusunan pembukuan sederhana. Pada sesi akhir, peserta diajak berdialog dengan tanya jawab menyangkut materi yang telah disampaikan. Sedangkan hasil evaluasi yang telah dilakukan untuk mengukur tingkat keberhasilan program kegiatan pengabdian ini, dapat dijabarkan sebagai berikut:

1. Pengetahuan serta serta minat dari para penggiat UMKM Emping Ceplis Melinjo Kelurahan Way Tataan tentang materi pengelolaan UMKM secara profesional.

2. Tingkat pengetahuan dan pemahaman para peserta yaitu anggota keluarga Ibu Kesuma Dewi selakuk pengelola Emping Ceplis Melinjo merk Sakina diukur dengan partisipasi yang berkembang dalam tanya jawab dan praktek ilustrasi pelatihan perhitungan contoh soal kasus penyusun pembukuan sederhana.

Berdasarkan data di lapangan nampak bahwa para peserta kegiatan pelatihan sangat 
memahami penjelasan materi yang disampaikan. Hal ini dibuktikan dengan berbagai macam pertanyaan yang diajukan serta diskusi.

\subsection{Evaluasi Kegiatan}

Evaluasi dalam kegiatan ini dilaksanakan dalam tiga tahap yakni

1. Tahap perencanaan kegiatan. Pada awal kegiatan ini, pemateri menjelaskan tentang materi yang akan disampaikan, yaitu kondisi riil UMKM Emping Ceplis Melinjo merk Sakina dengan kemasan bungkus plastik dan dilem dengan api lilin dan merk dibuat dengan seadanya denga kertas dan dibungkus plastik kemudian dimasukkan dalam plastik kemasan.

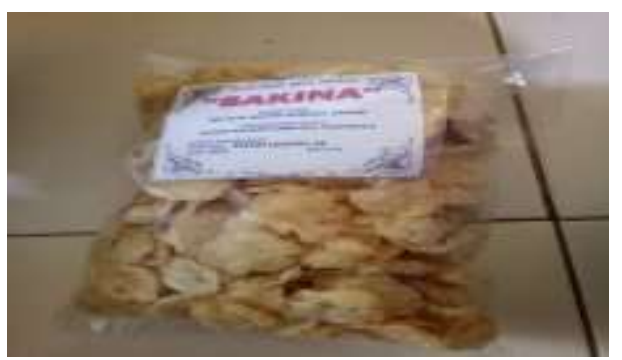

Gambar 1. Kemasan UMKM Emping Ceplis Melinjo di Kelurahan Way Tataan sebelum kegiatan Pendampingan

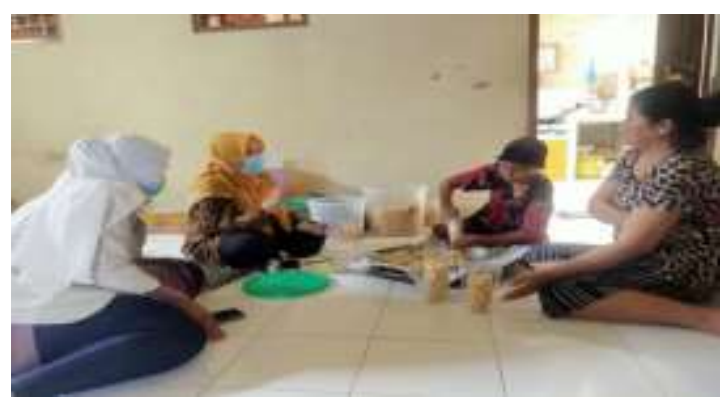

Gambar 2. Pendampingan UMKM emping ceplis melinjo merk Sakina di Kelurahan Way Tataan

2. Tahap selama proses kegiatan. Berdasarkan materi yang telah disampaikan peserta diberikan waktu dalam bertanya serta diskusi masalah yang berkaitan dengan materi. Tim Pengabdian memberikan usulan logo merk yang dibuat menarik menggunakan kertas stiker dan kemasan menggunakan plastik standing pouch.

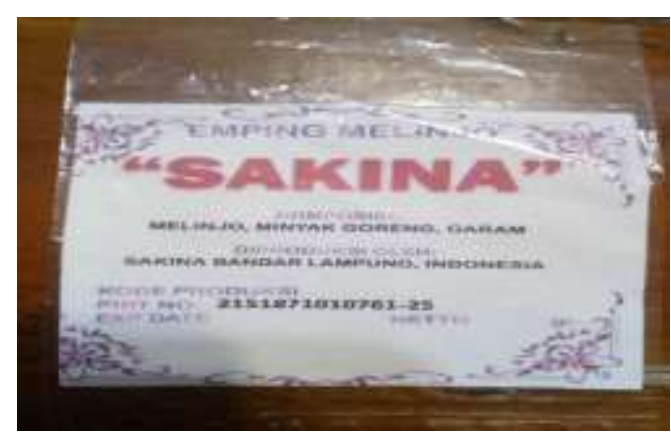

Gambar 3. Logo kemasan UMKM Emping Ceplis Melinjo sebelum kegiatan Pendampingan 


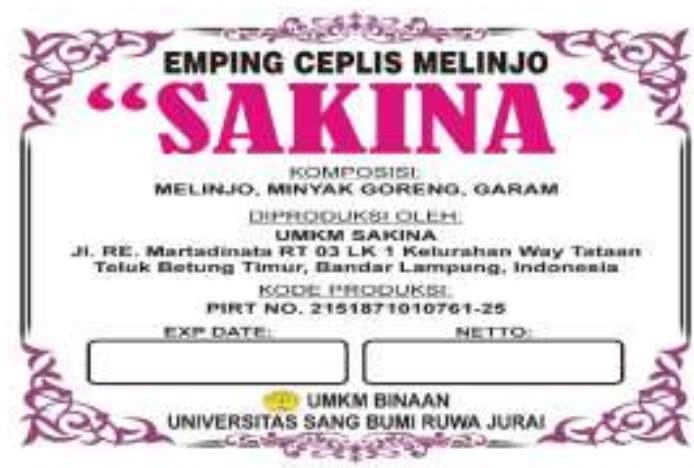

Gambar 4. Logo kemasan UMKM Emping

Ceplis Melinjo sesudah kegiatan Pendampingan

3. Tahap akhir kegiatan. Evaluasi pada akhir kegiatan ini dilakukan untuk mengukur keberhasilan dari seluruh program pelatihan ini. Evaluasi dilakukan melalui penilaian berdasarkan data di lapangan, Nampak bahwa para peserta pelatihan memahami penjelasan materi yang disampaikan. Hal ini terbukti dengan berbagai macam pertanyaan yang diajukan.

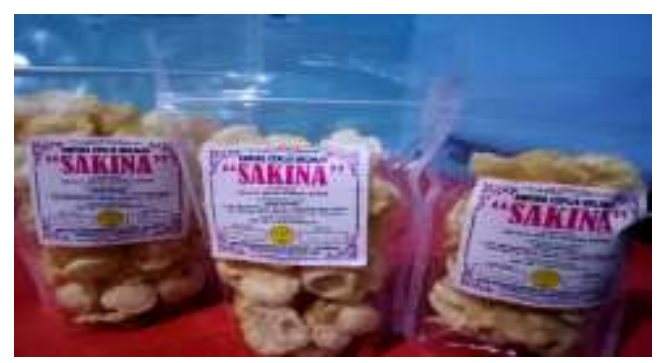

Gambar 5. Kemasan dan Logo UMKM Emping Ceplis Melinjo sesudah kegiatan Pendampingan

\section{SIMPULAN}

Berdasarkan pengabdian tersebut dapat ditarik kesimpulan bahwa pengelolaan UMKM Emping Ceplis Melinjo merk Sakina di Way Tataan yang dilakukan sampai saat ini belum profesional karena belum ada pencatatan atau pembukuan sederhana yang menjelaskan keuntungan bersih per bulan dari total penjualan dikurangi biaya produksi. Sedangkan kendala dalam pemasaran adalah pemasaran masih secara manual denga menitipkan produk emping ceplis melinjo di toko-toko pasar traditional atau warung -warung terdejat. SDM yang dimiliki keterbatasan pendidikan, dengan latar pendidikan lulusan SD. Tim pengabdian memberikan pelatihan penjualan secara online (daring) dengan menggunakan MarketPlace di akun Facebook atau membuat akun instragram yang adminnya dapat dibantu putra atau putri Ibu Kesuma Dewi.

Pelatihan Pengelolaan UMKM ini berjalan sangat aktif dan komunikatif. Awal pelatihan diberikan permainan untuk meningkatkan motivasi terhadap peserta yang merupakan satu keluarga yang terkait dengan produksi emping ceplis melinjo. Materi diberikan mengenai pemahaman pentingnya mengelola UMKM Emping Ceplis Melinjo secara profesional. Setelah diberikan materi yang berkaitan dengan strategi pemasaran secara online atau daring melalui MarketPlace 
(Facebook) maupun Instagram, pada akhirnya para peserta memahami materi dan termotivasi terlihat dengan antusiasnya peserta dalam berdiskusi.

\section{SARAN}

Berdasarkan pengabdian yang dilakukan, penulis mencoba memberikan beberapa saran yang diharapkan dapat bermanfaat :

1. Penggiat UMKM Emping Ceplis Melinjo merk Sakina diharapkan melakukan pencatatan secara sederhana mengenai aktivitas produksinya, sehingga dapat dibuatkan pembukuan sederhana setiap bulannya.

2. Adanya pembentukan koperasi yang mewadahi penggiat UMKM Pengolahan Emping Ceplis Melinjo di Way Tataan sehingga permasalahan dana yang menjadi hambatan usaha selama ini dapat terpecahkan.

3. Peningkatan kapasitas produksi Emping Ceplis Melinjo merk Sakina dengan memberikan bibit pohon melinjo atau tangkil kepada Ibu Kesuma Dewi untuk membantu permasalahan kekurangan bahan baku melinjo di masa mendatang.

4. Peningkatan Jumlah dan Kapasitas
SDM Pengolahan Emping Ceplis diluar anggota keluarga Ibu Kesuma Dewi dengan memberikan pelatihan kepada Ibu-ibu di Kelurahan Way Tataan untuk mau terlibat aktif dalam produksi pengolahan emping ceplis melinjo.

5. Adanya bantuan dan bimbingan dari Dinas koperasi dan UMKM Kata Bandar Lampung, pihak investor, masyarakat, dan Pemerintah Kata Bandar Lampung agar geliat UMKM di Kelurahan Way Tataan khususnya UMKM Emping Ceplis Melinjo ini dapat berkembang lebih baik lagi sehingga dapat meningkatkan pendapatan masyarakat Kelurahan Way Tataan terutama di masa pandemi Covid-19 yang sudah memasuki fase tahun kedua.

\section{UCAPAN TERIMA KASIH}

Tim pelaksana pengabdian masyarakat mengucapkan terimakasih kepada Lembaga Penelitian dan Pengabdian Kepada Masyarakat (LPPM) Universitas Sang Bumi Ruwa Jurai yang telah memberikan dukungan pendanaan.

DAFTAR PUSTAKA 
"Pengaruh BPHTB dan PBB terhadap Pendapatan Asli Daerah di Provinsi Kepulauan Riau," J. Aksara Public, vol. 1, no. 3, pp. 73-84, 2017, [Online]. Available:

http://akrabjuara.com/index.php/akrabjua ra/article/download/40/32/.

[2] I. W. R. Junaedi, I. W. Damayana, and D. Waruwu, "Model Pemberdayaan Ekonomi Masyarakat Adat Ekonomi Nasional (Studi Kasus Adat Betawi Dki Jakarta)," Pros. SNITT POLTEKBA, vol. 4, pp. 381-388, 2020.

[3] N. I. Imansari, "Praktikum Mengenai Kebutuhan Atau Utilitas Dalam Kehidupan Sehari-Hari," J. Masharif alSyariah J. Ekon. dan Perbank. Syariah, vol. 5, no. 2, 2020.

[4] I. N. Aji, B. A. Wibowo, and A. Asriyanto, "Analisis Faktor Produksi Hasil Tangkapan Alat Tangkap Cantrang Di Pangkalan Pendaratan Ikan Bulu Kabupaten Tuban,” J. Fish. Resour. Util. Manag. Technol., vol. 2, no. 4, pp. 5058, 2013, [Online]. Available: https://www.neliti.com/publications/1849 10/analisis-faktor-produksi-hasiltangkapan-alat-tangkap-cantrang-dipangkalan-pend.

[5] M. O. Adnyana and K. Kariyasa, "Dampak dan Persepsi Petani terhadap Penerapan Sistem Pengelolaan Tanaman Terpadu Padi Sawah," Penelit. Pertan.
Tanam. Pangan, vol. 25 , no. 1, pp. 2129, 2006.

[6] E. P. Lahu and J. S. B. Sumarauw, "Analisis Pengendalian Persediaan Bahan Baku Guna Meminimalkan Biaya Persediaan Pada Dunkin Donuts Manado," J. EMBA J. Ris. Ekon. Manajemen, Bisnis dan Akunt., vol. 5, no. 3, pp. 4175-4184, 2017, doi: 10.35794/emba.v5i3.18394.

[7] L. Anah, P. Haryanti, S. A. Masruroh, L. S. R. N., and S. A. Masruroh, "Modernisasi pengolahan pangan lokal hasil potensi desa kromong dan rancangan strategi pemasarannya," ABIDUMASY J. Pengabdi. Kpd. Masy., vol. 1, no. 1, pp. 42-48, 2020.

[8] M. Sari, S. Yanto, and M. Yahya, "Pembuatan Alat Pengepres Biji Melinjo Sebagai Teknologi Tepat Guna Untuk Mengolah Biji Melinjo Menjadi Emping," J. Pendidik. Teknol. Pertan., vol. 2, pp. 22-29, 2016, doi: 10.26858/jptp.v2i0.5182. 